\title{
Green synthesized nanomaterials as an alternative to restricted chemicals in postharvest preservation of horticultural crops: a review
}

\author{
Kwanele A. Nxumalo ${ }^{1}$ and Olaniyi A. Fawole ${ }^{1 *}$ \\ ${ }^{1}$ Postharvest Research Laboratory, Department of Botany and Plant Biotechnology, University of \\ Johannesburg, P.O. Box 524, Auckland Park, Johannesburg 2006, South Africa.
}

\begin{abstract}
Synthetic chemicals have been successfully used to control economic postharvest pathogens such as Botrytis cinerea, Penicillium spp., Rhizopus spp., etc., thus reducing postharvest losses. However, their active ingredient and co-formulants have resulted in their use being restricted internationally due to health concerns and consumers' requests for safe and natural alternatives. As an alternative to chemicals, green synthesized nanomaterials incorporated with edible coatings in a polymer matrix have been successfully applied on horticultural crops to improve their shelf-life Due to their known antimicrobial activities, plant extracts and nanoparticles such as silver and zinc oxide have been successfully used in food processing applications. Green sources are used as stabilizer and reducing agents to synthesize shape and sizecontrolled metal and metal oxide nanoparticles. Thus, eco-friendly nanoparticles are produced without using toxic materials and are cost-effective. Edible coatings form a thin layer that prevents oxidation, maintains the product quality, can be safely eaten as part of the product, and does not add unfavourable properties. Studies showed that edible coatings with or without green nanomaterials have been successfully used to control postharvest losses and improve the shelf-life of fruit crops such as plums, raspberries, etc.
\end{abstract}

*Corresponding author: nxumalokwaneleandy@gmail.com 


\section{Introduction}

Postharvest losses of fruits and vegetables are mainly caused by decay brought about by fungal plant pathogens [1]. According to the Food and Agricultural Organisation [2], one of the most feasible options for meeting future food needs is reducing postharvest losses. Postharvest losses pose a serious threat to the storage and marketability of fruits and vegetables, leading to nutrient loss and the spread of microorganisms responsible for degradation, leading to huge fresh produce losses[3-4]. Therefore, innovative technologies such as edible coatings (EC)[5] and controlled atmosphere (CA) are suggested as possible solutions for maintaining the quality of agricultural products during storage [3]. The spread of harmful microorganisms and the use of chemicals in postharvest preservation of horticultural crops poses a severe threat to the environment, crop quality and human health [6]. The application of green synthesized nanomaterial to control postharvest losses of horticultural crops has been generally regarded as safe [GRAS] to both the environment and human health [7-8]. The exceptional properties of green nanomaterials make them a practical choice for sustainable horticulture in general andin particular postharvest diseases of fruit and vegetable at the scientific and industry level[9]. The objective of this review was to document theapplication of green synthesized nanomaterials as an alternative to restricted chemicals in postharvest preservation of horticultural crops.

\section{Economic importance of postharvest losses of horticultural crops}

In the developing world, fruit and vegetable losses significantly impact poor and vulnerable people [2]. This comes in the form of social (health and livelihoods), environmental and economic costs[10]. According to FAO [11], about one-third of the edible parts of food produced for human consumption gets lost or wasted globally, which is about 1.3 billion tons per year. Food waste at the consumer level in industrialized countries (222 million tons) is almost as high as the total net food production in sub-Saharan Africa (230 million tons). Losses and waste in fruits and vegetables are the highest categories of losses among all types of foods, with up to 60 percent of all fruits and vegetables making their way to the landfill [2]. Horticultural losses impact food security for poor people, food quality and safety, economic development, and the environment [11]. Economically, postharvest losses of fruits and vegetables have a direct and negative impact on the income of both farmers and consumers [2], thus making food insecurity a question of access (purchasing power and prices of food) than a supply problem[10]. Improving the efficiency of the horticultural supply chain and reducing postharvest losses could reduce the high costs of fruits and vegetables and help bring down their cost and increase access for the consumers [10-11]. Given the high perishability of horticultural crops, the use of green nanomaterials, as an alternative to control postharvest losses, could be one way of reducing the economic cost of horticultural crops, improving their availabilityand increasing farmincome [9]. 


\section{Green nanomaterials as a viable alternative to control postharvest losses of horticultural crops}

The application of nanotechnology is largely promoted to develop active food packaging materials with excellent performance to protect horticultural crops and extend their shelf-life [12]. Promising performances of antimicrobial nano-coatings have been reported when they were applied on fresh fruits and vegetables [13-14]. Traditionally, nanoparticles (NPs) have been synthesized using physical and chemical methods and have high toxic residues, are expensive to produce, and are environmentally unfriendly [15]. Recently, green methods to synthesize metal-oxide nanoparticles have attracted much attention because they are simple, low cost and environment friendly [16-17]. These methods involve the use of plant, fruits, and vegetable extracts, which are used as stabilizers and reductant agents to control the crystal growth, and for scale-up and industrial production of NPs [18]. These plant extracts have organiccompounds, such as polyphenols that act as reductants and amino and carboxylic groups that may help as stabilizers, favouring the conversion of metal compounds into specific NPs [19]. The application of green nanomaterial to control postharvest losses of horticultural crops is summarised in Table 
Table 1. Application of green nanomaterial to control postharvest losses of horticultural crops

\begin{tabular}{|c|c|c|c|c|c|}
\hline $\begin{array}{c}\text { Green } \\
\text { material }\end{array}$ & $\begin{array}{l}\text { Synthesized } \\
\text { nanoparticle } \\
\mathrm{s}\end{array}$ & Fruit/vegetable & Focus of the study & Key findings & Reference \\
\hline $\begin{array}{l}\text { Citrus } \\
\text { sinensis peel } \\
\text { extract }\end{array}$ & $\begin{array}{c}\text { Zinc-oxide } \\
\text { NPs }\end{array}$ & Strawberries & $\begin{array}{l}\text { Application of Citrus sinensis nano- } \\
\text { coatings on fresh strawberries to } \\
\text { evaluatethe preservation effect }\end{array}$ & $\begin{array}{c}\text { Strawberries coated with citrus peel nanoparticles incorporated } \\
\text { into carboxymethylcellulosesodium (CMC) had decreased } \\
\text { weight loss, rate of rotting, and the storage quality was } \\
\text { improved }\end{array}$ & [20] \\
\hline$\alpha$-pinene & Chitosan & Bell pepper & $\begin{array}{l}\alpha \text {-pinene chitosan nanoparticles in } \\
\text { controlling to Alternaria alternate on } \\
\text { bell pepper }\end{array}$ & $\begin{array}{l}\text { The chitosan nanoparticles and edible coating inhibitedA. } \\
\text { alternata during the cold storage period of bell pepper and } \\
\text { preserved the physicochemical quality. }\end{array}$ & {$[21]$} \\
\hline $\begin{array}{c}\text { chitosan/gu } \\
\text { m } \\
\text { arabic } \\
(\mathrm{CH} / \mathrm{GA})\end{array}$ & ZnONPs & Banana & $\begin{array}{l}\text { ZnO NPs incorporated into } \\
\text { chitosan/gum Arabic }(\mathrm{CH} / \mathrm{GA}) \text { for the } \\
\text { preservation of bananas }\end{array}$ & $\begin{array}{l}\text { Banana coated with the } \mathrm{CH} / \mathrm{GA} / \mathrm{ZnO} \text { maintained freshness for } \\
\text { more than } 17 \mathrm{~d} \text { in comparison with the less than } 13 \mathrm{~d} \text { for the } \\
\text { control banana at } 35^{\circ} \mathrm{C} \text { and } 54 \% \mathrm{RH} \text {. }\end{array}$ & [22] \\
\hline $\begin{array}{l}\text { Olive and } \\
\text { marjoram } \\
\text { leaf extract }\end{array}$ & $\mathrm{ZnO}-\mathrm{NPs}$ & Bell pepper & $\begin{array}{l}\text { Evaluating disease management of gray } \\
\text { and black mold of pepper fruits } \\
\text { (artificially inoculated with the tested } \\
\text { two fungi) }\end{array}$ & $\begin{array}{l}\text { Results showed significant reduction to the appearance of both } \\
\text { diseases of pepper fruits treated with any of the two green } \\
\text { synthesized ZnO nanoparticles compared with chemically } \\
\text { synthesized ZnO-NPs and control. }\end{array}$ & [23] \\
\hline $\begin{array}{l}\text { Bergamot } \\
\text { essential oil } \\
\text { (BEO) }\end{array}$ & $\begin{array}{l}\text { Titanium- } \\
\text { NPS }\end{array}$ & Mango & $\begin{array}{l}\text { Effects of polylactic acid } \\
\text { (PLA)/BEO/nano-TiO2 film and } \\
\text { PLA/BEO/nano-TiO2 + nano-Ag in } \\
\text { maintainingthe quality of mangoes. }\end{array}$ & $\begin{array}{l}\text { Results with PLA and PLA/BEO films indicated that PLA NC } \\
\text { films successfully restricted adverse changes in total acidity, } \\
\text { vitamin C content, and color. At the same time, firmness } \\
\text { retention in the mangoes was enhanced. Results showed that } \\
\text { the shelf life of these fruits was extended up to } 15 \mathrm{~d} \text {. }\end{array}$ & [24] \\
\hline Carrageenan & $\mathrm{ZnO}-\mathrm{NPS}$ & Mango & $\begin{array}{l}\text { The effect of carrageenan/ZnO-NPs } \\
\text { (CZ) coating in maintaining the storage } \\
\text { quality of mango }\end{array}$ & $\begin{array}{l}\text { On d } 13 \text { of storage, the decline in the total acidity of mangoes } \\
\text { exposed to CZ } 0.5 \text { and } \mathrm{CZ} 1 \mathrm{NP} \text { coating treatments was } \\
\text { significantly lower than that in the control samples. The CO2 } \\
\text { production peak occurred after } 7 \mathrm{~d} \text { of storage, where the } \\
\text { mangoes in the control sample produced the highest level of } \\
\mathrm{CO} 2 \text {. Until day } 33 \text {, minimal degradation was evident in the }\end{array}$ & {$[25]$} \\
\hline
\end{tabular}




\begin{tabular}{|c|c|c|c|c|c|}
\hline & & & & $\begin{array}{c}\text { mangoes with } \mathrm{CZ} 0.5 \text { coatings compared to samples without } \\
\text { coatings. }\end{array}$ & \\
\hline Beeswax & $\begin{array}{l}\text { beeswax } \\
\text { solid lipid } \\
\text { nanoparticle } \\
\text { s (BSLN) }\end{array}$ & strawberry & $\begin{array}{l}\text { Nano-coatings with BSLN-with } \\
\text { xanthan gum }(\mathrm{XG}) \text { as an alternative in } \\
\text { the shelf life of strawberries stored in } \\
\text { refrigeration. }\end{array}$ & $\begin{array}{l}\text { The coating with } 10 \mathrm{~g} / \mathrm{L} \text { of BSLN, } 4 \mathrm{~g} / \mathrm{L} \text { of xanthan gum, and } 5 \\
\mathrm{~g} / \mathrm{L} \text { of propyleneglycol contributed positively to preservation } \\
\text { while also decreasing decay rates; reflected in less fungal } \\
\text { growth, weight loss, and physiological damage to the end of } \\
\text { storage. }\end{array}$ & [26] \\
\hline
\end{tabular}




\section{Antimicrobial and mechanism of action}

The efficacy of NPs in reducing microbial growth on fruits/vegetable surface is mainly dependent on the type, concentrationand properties of coating films, as well as the type, size, shape, concentration, chelation, release and photocatalytic properties of the applied NPs [27-28].The synergistic effect of coating materials and NPs in the barrier, the types and structure of tested microorganisms and the tested conditions could also influence antimicrobial activity of the applied green nanomaterial edible coatings [27, 29]. A study by Cano et al. [30] revealed that Ag-loaded films exhibited antimicrobial activity against postharvest pathogens such as Aspergillus niger and Penicillium expansum. However, the result appeared to be concentration dependent. Jia et al. [31] reported that silver/CS NPs exhibited a high effect on Botrytis cinerea fungi by suppressing the growth and germination at a concentration of $0.02 \mathrm{mg} / \mathrm{mL}$ in vitro and in vivo. Similarly, El-Sherbiny et al. [32] indicated that $100 \mu \mathrm{l} / \mathrm{mlAg}-\mathrm{NPs}$ and the in-situ development of Ag-NPs on the surface of

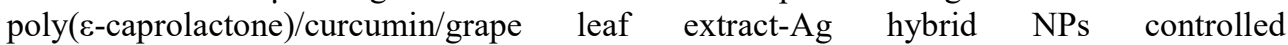
Aspergillusflavus. These antimicrobial activities could significantly contribute to controlling the decay and quality loss of horticultural crops during storage or when exported [3,14]. Otoni et al. [33] and Goudarzi et al. [34]reported that nanoparticles and edible coatings (EC) act directly on the pathogen by inhibiting spore germination and mycelium growth and altering morphological structures and reactive oxygen species (ROS) generation, spore mitochondrial membrane potential (MMP) and adenosine triphosphate (ATP) content.The preservation mechanism includes gas modification and induction defence properties of EC with NPs by forming a thin coating film on the surfaces of fresh products after being treated and dried, thus, modifying the concentrations of $\mathrm{O} 2, \mathrm{CO} 2$, and ethylene produced by horticultural crops [3, 14, 35].

Gao et al. [36] reported that strawberries coated with carboxymethylcellulose (CMC) enriched with $\mathrm{ZnO}$ nanoparticles synthesized from Citrus sinensis peel extract (CMC/CSP) had higher efficacy in controlling Botrytis cinerea compared to CMC enriched with commercial $\mathrm{ZnO}$ nanoparticles $(\mathrm{CMC} / \mathrm{CZN})$. Strawberries coated with $\mathrm{CMC} / \mathrm{CSP}$ showed a lower rate of rotting and increased the storage period by $2 \mathrm{~d}$ compared to the other treatments. The higher antifungal activity of the CMC/CSP damaged the DNA and protein of the postharvest pathogen resulting in their cells death, thus reducing its severity and preserving the quality of the fruit for a longer time. An in vitro study by Saekow et al. [37] found that $\mathrm{ZnO}-\mathrm{NPs}$ synthesized from pineapple peel extracts in $\mathrm{CMC}$ coating delayed the severity of Alternaria alternata persimmon and tomato fruit.After $3 \mathrm{~d}$, results showed that control fruit had a progressive higher disease development in the early stage of the storage period. Contrary to the control, $\mathrm{CMC}+\mathrm{ZnONPs}$ coated persimmon and tomato hada lower level of disease development started showing signs of diseases development at $6 \mathrm{~d}$ of storage. Sing [38] reported that zinc oxide nanoparticles have a strong good antifungal activity against selected strains of bacteria and fungus compared to conventional zinc oxide particles.

\section{Conclusion and future prospects}

Green nanomaterials have emerged as an alternative to fungicides and have proven costeffective and have high efficiency in maintaining fruit/vegetable quality. The low cost, environmentally benign, low-toxicity, and good performance green nanomaterials show a 
great potential to be applied in postharvest preservation of horticultural crops. For this reason, research efforts are needed to enhance our knowledge in the application of nanotechnology in postharvest technology. Currently, there is a dart of knowledge on how the synthesis of green nanomaterials could be optimized for high yield and efficacy in the protection of horticultural crops. In addition, long termrisks and hazards of the use of nanomaterial remain unknown. There is a need to investigate this area and be cautious with the use of certain metaloxides such as TiO2and $\mathrm{X}$, which have been studied to cause detrimental adverse factors such as colon cancer in humans. Finally, factors, including dose, kind of nanomaterials, application timing, and fruit/vegetable physiology, can affect the efficacy of nanomaterials; therefore, this area also requires further investigation.

\section{References}

1. P. Tripathi, N. Dubey. Postharvest Biol. Technol. 32:235-245 (2004)

2. Food and Agriculture Organization of the United Nations (FAO). Agricultural markets and sustainable development: Global value chains, smallholder farmers and digital innovations. Rome, FAO. https://doi.org/10.4060/cb0665en (2020)

3. Y. Xing, W. Li, Q. Wang, X. Li, Q. Xu, X. Guo, X. Bi, X. Liu, Y. Shui, H. Lin, H. Yang. Molecules. 24: 1695 (2019)

4. O.A. Fawole, S.C. Riva, U.L. Opara. Agronomy. 10:1-21 (2020)

5. S.C. Riva U.O. Opara, O.A. Fawole. Scientia Horticulturae. 262: 109074 (2020)

6. Food and Agriculture Organization (FAO) and the World Health organisation (WHO) of the United Nations. WHO, Geneva, Switzerland (2013)

7. L.A. Castillo, O.V. López, J. Ghilardi, M.A. Villar, S.E. Barbosa, M.A. García. Food Hydrocoll. 51: 432-440. (2015)

8. I. Shahabi-Ghahfarrokhi, F. Khodaiyan, M. Mousavi, H. Yousefi. Int. J. Biol. Macromol. 77: 85-91 (2015)

9. S. Ruffo Roberto, K. Youssef, A.F. Hashim, A. Ippolito. Nanomaterials. 9:1752(2019)

10. J. Gastavsson, C. Cederberg, U. Sonesson. Food and Agriculture Organization (FAO) of the United Nations: Rome, Italy (2011)

11. Food and Agriculture Organization of the United Nations (FAO). Accessed 17 November 2020 (2017).

12. D. Bhuyan, G.W. Greene, R.K. Das. Critic. Rev. Biotech.39(6):759-778 (2019)

13. B.J. Arroyo, A.C. Bezerra, L.L. Oliveira, S. J. Arroyo, E.A.D. Melo, A.M.P. Santos. Food Chem.125566(2019).

14. K.A. Nxumalo, A.O. Aremu, O.A. Fawole. Sustainability 13:5897 (2021)

15. O.J. Nava, C.A. Soto-Robles, C.M. Gómez-Gutiérrez, A.R. Vilchis-Nestor, A. Castro-Beltrán, A. Olivas, P.A. Luque. J. Molec. Struc. 1147:1-6 (2017).

16. A.K. Mittal, Y. Chisti, U.C. Banerjee. Biotech. Adv.31(2):346-356 (2013)

17. K. Elumalai, S. Velmurugan. Appl. Surf. Sci. 345: 329-336 (2015)

18. F. Davar, A. Majedi, A. Mirzaei, J. Am. Ceram. Soc. 98(6):1739-1746 (2015)

19. M. Stan, A. Popa, D. Toloman, A. Dehelean, I. Lung, G. Katona. Mat.Scie.Semicond. Proc. 39: 23-29 (2015)

20. Y. Gao, D. Xu, D. Ren, K. Zeng, X. Wu. Lwt.126:109297 (2020)

21. G. Hernández-López, R.I. Ventura-Aguilar, Z.N. Correa-Pacheco, S. BautistaBaños, L.L. Barrera-Necha. Int. J.Bio.Macrom.165:1881-1888 (2020) 
22. D.D. La, P. Nguyen-Tri, K.H. Le, P.T.M. Nguyen, M.D. Nguyen, A.T.K. Vo, M.T.H. Nguyen, S.W. Chang, L.D.Tran, W.J. Chung, D.D. Nguyen. Prog. Org. Coat.151:106057 (2021).

23. M. Hassan, M.A. Zayton, S.A. El-Feky. J. Biotech.Bioengin.3(4):8-15 (2019)

24. H. Chi, S. Song, M. Luo, C. Zhang, W. Li, L. Li, Y. Qin. Sci. Hortic. 249: 192198 (2019)

25. B. Meindrawan, N.E. Suyatma, A.A. Wardana, V.Y. Pamela.Food Packag.Shelf Life.18:140-146 (2018).

26. M.L. Zambrano-Zaragoza, D. Quintanar-Guerrero, A. Del Real, R.M. GonzálezReza, M.A. Cornejo-Villegas, E. Gutiérrez-Cortez. Coatings. 10:253 (2020)

27. S.S. Soni, G.S. Dave, M.J. Henderson, A. Gibaud. Thin Solid Films. 531: 559-565 (2013)

28. Y. Xing, Q. Xu, L. Jiang, D. Cao, H. Lin, Z. Che, Y. Ma, X. Li, Y. Cai. RSC Adv. 5: 22825-22837 (2015).

29. Q. Xu, Y. Xing, Z. Che, T. Guan, L. Zhang, Y. Bai, L. Gong. J. Food Saf. 33: 179$189(2013)$

30. A. Cano, M. Cháfer, A. Chiralt, C. González-Martínez. Shelf Life. 10:16-24 (2016).

31. R. Jia, H. Jiang, M. Jin, X. Wang, J. Huang. Food Res. Int. 78: 433-441 (2015)

32. I.M. El-Sherbiny, A. El-Shibiny, E. Salih. J. Photochem. Photobiol. B.160:355$363(2016)$

33. C.G. Otoni, R.J. Avena-Bustillos, H.M.C. De Azeredo, M.V. Lorevice, M.R. de Moura, L.H.C. Mattoso, T. McHugh. Compr. Rev. Food Sci. Food Saf. 16: 11511169 (2017)

34. V. Goudarzi, I. Shahabi-Ghahfarrokhi. Int. J. Biol. Macromol. 106: 661-669 (2018)

35. H. Song, W. Yuan, J. Peng, W. Wei, X. Wang, L. Yang, Y. Zhang. Postharvest Biol. Technol. 119: 41-48 (2016)

36. Y. Gao, D. Xu, D. Ren, K. Zeng, X. Wu. Lwt, 126:10929 (2020)

37. M. Saekow, M. Naradisorn, W. Tongdeesoontorn, Y. Hamauzu. J. Food Scie. Agric. Technol. 5 (Spcl. Iss.): 41-4 (2019).

38. S. Sing. Toxicol. Mechan. Met. 29(1):37 (2018) 